\title{
Anaplastic Lymphoma
}

National Cancer Institute

\section{Source}

National Cancer Institute. Anaplastic Lymphoma. NCI Thesaurus. Code C6916.

A diffuse large B-cell lymphoma variant characterized by the presence of large round, oval, or polygonal cells with bizarre pleomorphic nuclei resembling Hodgkin or ReedSternberg cells. It is unrelated to anaplastic large cell lymphoma which is a T-cell nonHodgkin lymphoma. 